\title{
Current global warming appears anomalous in relation to the climate of the last 20000 years
}

\author{
Svante Björck* \\ Department of Earth and Ecosystem Sciences, Division of Geology, Quaternary Sciences, Lund University, Sölveg. 12, \\ 22362 Lund, Sweden
}

\begin{abstract}
To distinguish between natural and anthropogenic forcing, the supposedly ongoing global warming needs to be put in a longer, geological perspective. When the last ca. $20000 \mathrm{yr}$ of climate development is reviewed, including the climatically dramatic period when the Last Ice Age ended, the Last Termination, it appears that the last centuries of globally rising temperatures should be regarded as an anomaly. Other, often synchronous climate events are not expressed in a globally consistent way, but rather are the expression of the complexities of the climate system. Due to the often poor precision in the dating of older proxy records, such a statement will obviously be met with some opposition. However, as long as no globally consistent climate event prior to today's global warming has been clearly documented, and considering that climate trends during the last millennia in different parts of the world have, in the last century or so, changed direction into a globally warming trend, we ought to regard the ongoing changes as anomalies, triggered by anthropogenically forced alterations of the carbon cycle in the general global environment.
\end{abstract}

KEY WORDS: Global warming $\cdot$ Long-term perspective $\cdot$ Climate anomaly

\section{BACKGROUND}

'The past is the key to the present and the future' is a phrase often used by geologists to explain how their knowledge can be used by society. It is, however, also a well-known fact that each moment in Earth's history is unique, which implies that there are no perfect analogues for today's world or any modeled future scenarios. This is certainly true for the ongoing trend of global warming. The best analogue to a global warming scenario similar to what is expected in the coming centuries, and with some detailed and robust data, may be the Last Interglacial (LIG) with its warmer climate, globally coherent or not, but without increased greenhouse gases (GHGs). Instead, Earth's orbital eccentricity was more than twice today's value during large parts of the LIG (Berger \& Loutre 1991), resulting in an overall increase in continental summer temperatures (Antarctica excluded) with at least $0.5^{\circ} \mathrm{C}$ (Crowley \& Kim, 1994) between 132 and 124 kiloyears (kyr) BP. Furthermore, Arctic summers were possibly 2 to $4^{\circ} \mathrm{C}$ warmer (Otto-Bliesner et al. 2006) and, as expected, this resulted in higher sea levels and smaller ice sheets on Greenland and West Antarctica (e.g. Overpeck et al. 2006). The estimations of the maximum sea level stand during the LIG vary greatly, but according to Kopp et al.'s (2009) integrated analysis of globally distributed LIG data sets, it was 6.6 to $>8 \mathrm{~m}$ higher than present. Although such scenarios are not directly valid for the present and nearest future, it shows how vulnerable interglacial glaciers and ice sheets may be to global warming and rising sea levels. In the light of these LIG reconstructions and the wellknown Arctic amplification effect (IPCC 2007), the concentration of glacial ice around higher latitudes will most likely not prevent it from melting in a warmer world.

Since the Last Glacial Maximum (LGM) 26500 to 20000 yr ago (Clark et al. 2009), Earth has undergone profound changes: the large continental ice sheets in the Northern Hemisphere (NH) have vanished (with the exception of the Greenland ice sheet), the Antarctic ice 
sheet has diminished considerably, local mountain ice caps have disappeared (and partly resurfaced in the late Holocene) and global paleogeography has changed considerably due to the coastal evolution caused by the 120 to $140 \mathrm{~m}$ rise of sea level generated by the melting ice sheets (e.g. Lambeck \& Chappell 2001, Peltier 2007). As a consequence, and with a complex development of a continuously variable world throughout these $20000 \mathrm{yr}$, our planet looks very different today compared with the LGM situation. By combining proxies from marine, terrestrial and ice core records from different parts of the globe, it is possible to examine the general climate development since the LGM, and relate and compare these changes to the Intergovernmental Panel on Climate Change (IPCC) reports of the last few centuries of what a majority of researchers regard as a global warming. However, it is not possible to perform a totally flawless analysis on this issue, especially not in a context with very restricted space: the topic is huge. This is partly due to the wealth of data available; in addition, it is problematic to compare, in a statistically sound way, extremely detailed meteorological data of the last century with different types of geologic proxy data of varying time resolution. Instead, I will try to present a short overview of the global climate development since the LGM and put the last $150 \mathrm{yr}$ of the so-called global warming into a more long-term geological context.

\section{THE LAST TERMINATION}

An intriguing feature of the end of the last ice age, the Last Termination, is the step-wise and oscillating warming-cooling scenarios displayed in most of the $\mathrm{NH}$ records (e.g. Haflidason et al. 1995, Björck et al. 1996, Wang et al. 2001, Andersen et al. 2004), compared to the gradual and more or less continuous warming in most of the Southern Hemisphere (SH) and large parts of the equatorial regions (e.g. Lea et al. 2000, Stott et al. 2007). While the complex climate trend of the north is well-mirrored by the development of, for example, atmospheric $\mathrm{CH}_{4}$ content (Blunier et al. 1998), which is directly coupled to the temperature changes of the land mass-dominated $\mathrm{NH}_{\text {, where most }}$ of the methane is produced, atmospheric $\mathrm{CO}_{2}$ content and many $\mathrm{SH}$ temperature curves almost 'go hand-in-hand' (Monnin et al. 2001), often explained by changes in sea ice extent and thereby ventilation of the Southern Ocean (Marchitto et al. 2007, Fischer et al. 2010). In the $\mathrm{NH}$, the first, although weak, trend of rising post-LGM temperatures begins slightly before 20000 calendar yr BP (cal yr BP) (Andersen et al. 2004), preceding the southern rise by more than $2000 \mathrm{yr}$. On the other hand, this first large deglacial warming in mid-high southern latitudes began several millennia before a correspondingly significant warming abruptly started in the mid-high latitudes of the north at ca. 14600 cal yr BP, defining the onset of the Greenland Interstadial 1 (GI-1) (Björck et al. 1998), preceded by the so-called mystery interval (Broecker \& Barker 2007).

When the interhemispheric climate relationships of the Last Termination are compared more in detail, often with the aid of the well-dated ice cores from Greenland and Antarctica and in combination with sea temperature proxies (e.g. Barker et al. 2009), a bipolar seesaw pattern emerges. The details of the mechanism behind this pattern have been discussed and are not clear, but changes in the Atlantic meridional overturning circulation (AMOC) certainly play a key role behind the underlying processes. When the AMOC in the north is disturbed by, for example, outbursts and/or large volumes of glacial melt-water, the meridional heat transport (from south to north) is seriously hampered. This results in a cooling in the north, while warmer waters reside in the Southern Ocean with a southerly displacement of sea ice and warming of the atmosphere. Furthermore, there seems to be a direct relation between the duration of the Greenland stadials and the degree of the Antarctic warmings (EPICA Community Members 2006). In general, the glacial climatic anti-phase relationship (with some phase lags) between the 2 hemispheres, the so-called bipolar seesaw mechanism, continued at least until ca. $12000 \mathrm{cal}$ yr BP and perhaps also throughout the Holocene (Ljung \& Björck 2007, Maslin \& Smart 2010), and the data available strongly indicate that there is no common global warming (or cooling) event during the Last Termination.

\section{EARLY HOLOCENE}

At the distinct onset of the Holocene Series/Epoch, as defined by Walker et al. (2009), and warming in the $\mathrm{NH}$, large parts of the SH had already been continuously warming for at least $1000 \mathrm{yr}$. During the subsequent deglaciations of the $\mathrm{NH}$ and Antarctic continental ice sheets, as well as the large mountainous ice sheets of the Rocky Mountains, Andes and Himalaya, huge amounts of freshwater were discharged into the ocean during a fairly short time; the sea level rose ca. $60 \mathrm{~m}$ in less than $6000 \mathrm{yr}$ (Siddall et al. 2003). These often periodic freshwater pulses seem to have caused recurrent perturbations of both the atmospheric and marine circulation patterns. This is probably the main reason why the climate of the higher (especially northern) latitudes in the early Holocene displays a seemingly chaotic behavior. However, when marine, ice core and terrestrial records are compared from these 

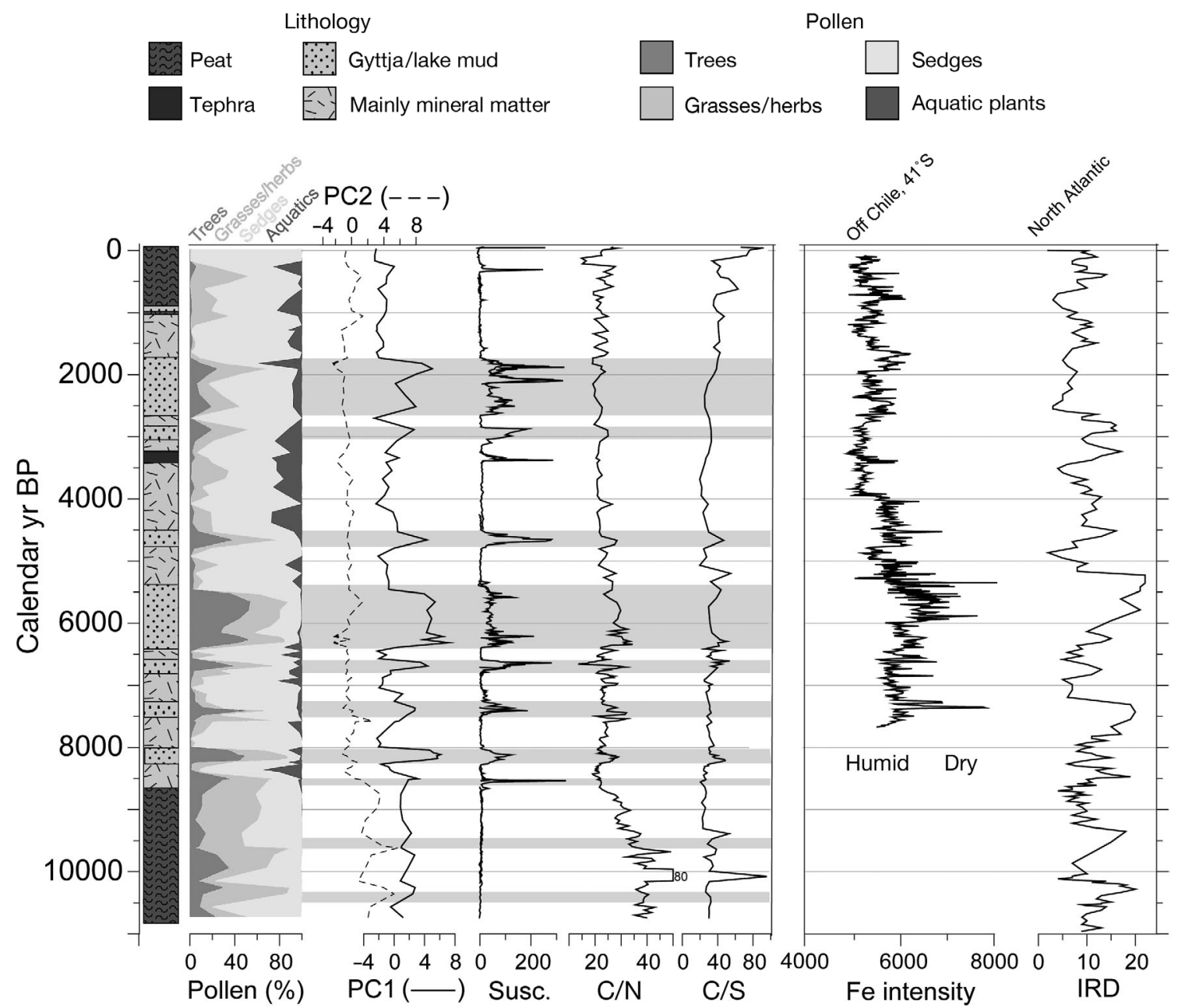

Fig. 1. A unique Holocene record from an overgrown lake, 2nd Pond, on Nightingale Island in the South Atlantic $\left(37^{\circ} \mathrm{S}, 12^{\circ} \mathrm{W}\right)$, situated in the Tristan da Cunha island group between Cape Town and Montevideo. Shown are the lithology, pollen and geochemistry records from the 2nd Pond basin, including Principal Components 1 and 2 (PC1, PC2; after Ljung \& Björck 2007). Peaks of the $\mathrm{C} / \mathrm{N}$ ratio and magnetic susceptibility (Susc; $10^{-6} \mathrm{SI}$ units) record imply increased input of terrestrial organic and mineral matter, respectively, indicating periods of increased precipitation, while the C/S ratios imply varying input of aerosols and/or sea spray. Also note that high PC1 values are interpreted as increased precipitation, i.e. increased in-wash of pollen from more distant growing trees. Horizontal shaded stripes mark periods with increased precipitation. This record is compared with the Fe intensity (XRF counts $\mathrm{s}^{-1}$ ) record in a marine core off Chile (Lamy et al. 2001), indicating higher or lower precipitation in central Chile, and a stacked record of hematite-stained grains, interpreted as ice rafted debris (IRD; amount of hematite-stained grains, expressed as percentage of lithic grains in the 63-150 $\mathrm{m}$ size range), in marine cores in the North Atlantic (Bond et al. 2001), implying more or less sea-ice and icebergs

different regions it is not difficult to find consistent climate oscillations within each region, consistent trends within each hemisphere-possibly insolation-forcedand even some roughly synchronous interhemispheric oscillations (Fig. 1). It is, however, virtually impossible to find evidence for globally synchronous climate events with the same climate signature, for example warmings or coolings. In terms of possible forcing mechanisms, apart from freshwater outbursts, some of the events have been assigned to still partly unknown climate-related processes, such as decreased solar activity or irradiance and/or increased cosmogenic radiation (e.g. Björck et al. 2001, Bond et al. 2001).
The high summer insolation to lower (northern) latitudes and the meridional displacement of the Intertropical Convergence Zone (ITCZ), as a boreal summer perihelion effect of the precession cycle, strengthened the monsoon in many subtropical regions. Although this led to a fairly stable climate on these lower latitudes during the first few millennia of the Holocene-often with warm and humid summers as a consequence - there is also ample evidence for a link between North Atlantic climate and the Asian Monsoon (AM). High-resolution analyses of Chinese stalagmites (Wang et al. 2005) show that many of the ice-rafted debris (IRD) events in the North Atlantic 
(Bond et al. 2001) correlate very well to weakened AM events. According to Wang et al. (2005), some of these were possibly triggered by changes in AMOC such as, for example, during the so-called $8.2 \mathrm{kyr}$ event (Alley et al. 1997), but some also correlate to changes in solar output as revealed by, e.g. comparisons to the atmospheric $\delta^{14} \mathrm{C}$ record. Thus, examples of how common triggers result in various climate scenarios in different parts of the world are very common and seem to be a normal feature.

\section{MID-HOLOCENE}

Around $6000 \mathrm{cal}$ yr BP, only 2 major inland ice sheets remained: the huge Greenland and Antarctic ice caps. However, modeling and data from the southern Greenland ice sheet imply that it was considerably smaller in the early-mid Holocene than today (Jönsson Sparrenbom 2006, Vinther et al. 2009), and new data from Iceland indicate that the Vatnajökull ice cap may perhaps have disappeared in the mid-Holocene (Striberger et al. 2009). In addition, it is very likely that many of the alpine glaciers had also melted as a consequence of the high summer insolation of the early Holocene, and did not begin to build up until in the later part of the Holocene. As a direct consequence, the sea level rise had more or less reached today's or even slightly above today's level (Yu \& Zhao 2010) due to glacier melt. So in terms of ice sheet extent and sea levels, the mid-Holocene world did not look totally different from today's world.

However, in spite of the absence of the large continental ice sheets that had previously covered large parts of Eurasia and North America and, thereby, the absence of this large potential in impacting the climate system, paleoclimate records show that climate variability continued. The frequency of this variability varies between regions, latitudes and time periods. By analyzing a large set of Holocene records (Wanner et al. 2008), the spectral peaks are found in a band between 100 and $2200 \mathrm{yr}$, and no global consistency regarding the character of climate events can be found. Some events may be synchronous, e.g. the IRD pulses in the North Atlantic (Bond et al. 2001) and precipitation events in the South Atlantic (Ljung \& Björck 2007; see Fig. 1), but their nature in terms of temperature, precipitation, etc., never seems globally consistent. However, some general long-term trends can be seen in several records, and this is most likely connected to gradual changes in the insolation-related parameters: for example, a cooling trend in the northeast Atlantic region (e.g. Andresen et al. 2006), decreasing strength of the AM (e.g. Fleitmann et al. 2003) and decreased intensity of the Southern Hemisphere westerlies in southern South America (e.g. Unkel et al. in press), all superimposed on a series of oscillations. Although many of these oscillations may be more or less synchronous, they represent the natural variability and complexity of the climate system triggered by a variety of mechanisms, often stochastic in their nature, ultimately produced by insolation and seasonality changes and possibly also by a combination of other external (e.g. solar forcing) as well as internal (e.g. volcanism and carbon cycle changes) factors.

\section{LATE HOLOCENE}

The last few thousand years have been studied in great detail by several research groups and in many multidisciplinary projects, e.g. the EU Millennium project (http://ralph.swan.ac.uk/millennium/), and global consistency regarding climatic changes is difficult to find evidence for. The often-cited climate pattern of the last 2000 to 3000 yr with the Roman Warm Period, the Dark Cold ages, the Medieval Warm Period and the Little Ice Age (LIA) seems to be restricted to the $\mathrm{NH}$ or parts of it, and does not show up as a global pattern of warmings and coolings. In fact, these changes, as well as the often more or less synchronous changes in the $\mathrm{SH}$, seem to be the result of a temporally variable atmospheric and marine circulation pattern, with e.g. meridional shifts of the Hadley cells, ITCZ and ocean currents, and in part also changing solar variability and/or forcing and fluxes of cosmogenic radionuclides. Although the latter 2 should have more or less global impacts, too little is known about the underlying climate-related mechanisms and how they may trigger different processes in the atmosphere and/or cryosphere.

In their mid- to late Holocene overview, Wanner et al. (2008) performed an interesting comparison on climate-related trends between $6000 \mathrm{cal}$ yr BP and 1700 AD. These long-term trends can usually be explained by insolation changes; e.g. decreasing summer insolation to mid-high northern latitudes explains cooling conditions in Arctic Canada, Greenland and northwestern Eurasia as well as the southwards displacement of the Arctic tree line. In addition, decreasing summer insolation to subtropical latitudes explains a weaker monsoon and a southwards shift of ITCZ. However, most of these insolation-related trends have clearly broken down during the last century, implying that an additional and important mechanism is now in action. This reversal of long-term trends is probably most significant in the Arctic, where climate reconstructions show that, for example, 4 of the 5 warmest decades of the last 2000 yr occurred during the last 5 decades of the 20th century (Kaufman et al. 2009). 
It has long since been argued that the occurrence of the Maunder sunspot minimum during the 'heart of' the LIA shows the climatic importance of changes in solar activity and/or irradiance (Eddy 1976), an argument also often put forward to explain at least the onset of global warming and high solar activity during the early 20th century. In this respect it is important to note that while the LIA was not a period of global cooling, but a rather complex period of climate change, the last 100 to 150 yr have seen an almost globally consistent warming. Moreover, reconstructions of solar activity during the last millennium are not consistent (Bard et al. 2000, Usoskin et al. 2003), but it seems clear that the solar activity of the last 50 to 60 yr was not exceptional and has been at this or higher levels several times during the last millennium (Muscheler et al. 2007). For many reasons it is therefore not too controversial to state that the warming of the last century comes across as an anomalous climate event, not only in the perspective of a few centuries to a few millennia but also on longer time scales.

\section{CONCLUSIONS}

I find it fair to conclude that in the perspective of 10 to 20 millennia, the ongoing global warming seems to be an anomaly. Owing to often incomplete chronologies of the proxy based paleo-archives, especially in relation to the last $150 \mathrm{yr}$ of daily to annual instrumental records, it may, however, be difficult to find clearcut evidence for such a statement. One might also ask the question: What is the likelihood of seeing a global warming in our proxy records of comparable magnitude to the present warming, and arising only due to natural variations? A statistically reliable answer is of course difficult to give, but with the gradually increased focus on high-resolution records, I would be surprised if it would not have been found in many of our records.

Then again, as geologists we could try to put the ongoing warming into a thought experiment. Firstly, if we use the $8.2 \mathrm{kyr}$ cooling event in the $\mathrm{NH}$ (Alley et al. 1997, Hammarlund et al. 2005), which lasted less than $100 \mathrm{yr}$, as a Holocene analogue of a partly enigmatic climate event, we cannot say for certain what triggered it. How can we try to better understand the underlying processes behind it? Perhaps by climate modeling? In fact, modeling of available data on early Holocene cooling events (Renssen et al. 2007) shows that this event was most likely triggered by freshwater outbursts that severely disturbed the thermohaline circulation and meridional heat advection to the north. This fits well with the geological observations that a large North American glacial lake was drained out into the
North Atlantic at that time, i.e. a normal procedure: testing models with data and vice versa. Secondly, if we found a short geologic warming event during, for example, the Holocene, and were able to analyze proxies from that period which disclosed that, for example, aerosols and solar activity had been rather high and that GHGs were $>30 \%$ higher than during the preceding period, what conclusions would we have drawn? With data in a quantifiable form, modeling attempts would certainly have been carried out to find out the most likely hypothetic mechanisms behind the warming. After critical analyses of the data and repeated model runs, I think it is likely that geologists and/or geoscientists would find that the high atmospheric GHGs would be the main candidate for the warming, but perhaps with a reservation concerning the effects from increased solar forcing. The type of procedures described above is what the IPCC modelers have performed, by testing different climate scenarios, such as ones with or without increased GHGs, etc.

To summarize, as long as there is no positive and clear evidence for distinct, globally synchronous climate events (since the LGM) with consistent climate signals, we should consider the ongoing global warming as an anomalous climate event, possibly with a global forcing mechanism-increasing atmospheric content of GHGs - altering the energy budget of the Earth. The basis behind and consequences of such a standpoint can obviously be discussed, but the effects of our giant 'climate experiment' are undoubtedly difficult to estimate and evaluate since we have no past analogues to a situation with abruptly rising GHGs more than $10000 \mathrm{yr}$ into an interglacial period. We should therefore be cautious about how and to what degree we contaminate our environment and both directly and indirectly influence natural climate processes: the dangers of crossing climate thresholds in a greenhouse world have been pointed out by many scientists (e.g. Stocker 1999, Alley et al. 2003, Keller et al. 2008).

\section{LITERATURE CITED}

Alley RB, Mayewski PA, Sowers T, Stuiver M, Taylor KC, Clark PU (1997) Holocene climatic instability: a prominent widespread event 8200 years ago. Geology 25:483-486

Alley RB, Marotzke J, Nordhaus WD, Overpeck JT and others (2003) Abrupt climate change. Science 299:2005-2010

Andersen KK, Azuma N, Barnola JM, Bigler M and others (2004) High-resolution record of Northern Hemisphere climate extending into the last interglacial period. Nature 431:147-151

Andresen CS, Björck S, Rundgren M, Conley D, Jessen C (2006) Rapid Holocene climate changes in the North Atlantic: evidence from lake sediments from the Faroe Islands. Boreas 35:23-34 
Bard E, Raisbeck GM, Yiou F, Jouzel J (2000) Solar irradiance during the last 1200 years based on cosmogenic nuclides. Tellus 2B:985-992

Barker S, Diz P, Vautravers MJ, Pike J, Knorr G, Hall IR, Broecker WS (2009) Interhemispheric Atlantic seesaw response during the last deglaciation. Nature 457: 1097-1103

Berger A, Loutre MF (1991) Insolation values for the climate of the last 10 million years. Quat Sci Rev 10:297-317

Björck S, Kromer B, Johnsen S, Bennike O and others (1996) Synchronized terrestrial-atmospheric deglacial records around the North Atlantic. Science 274:1155-1160

Björck S, Walker MJC, Cwynar LC, Johnsen S, Knudsen KL, Lowe JJ, Wohlfarth B, INTIMATE Members (1998) An event stratigraphy for the last termination in the North Atlantic region based on the Greenland ice-core record: a proposal by the INTIMATE group. J Quaternary Sci 13: 283-292

Björck S, Muscheler R, Kromer B, Andresen CS and others (2001) High-resolution analyses of an early Holocene climate event may imply decreased solar forcing as an important climate trigger. Geology 29:1107-1110

Blunier T, Chappellaz J, Schwander J, Dallenbach A and others (1998) Asynchrony of Antarctic and Greenland climate change during the last glacial period. Science 349: 739-743

Bond G, Kromer B, Beer J, Muscheler R and others (2001) Persistent solar influence on North Atlantic climate during the Holocene. Science 294:2130-2136

Broecker W, Barker SA (2007) A 190\% drop in atmosphere's $\delta^{14} \mathrm{C}$ during the 'mystery interval' (17.5-14.5 kyr). Earth Planet Sci Lett 256:90-99

Clark PU, Dyke AS, Shakun JD, Carlson AE and others (2009) The Last Glacial Maximum. Science 325:710-714

Crowley TJ, Kim KY (1994) Milankovitch forcing of the Last Interglacial sea level. Science 265:1566-1568

Eddy JA (1976) The Maunder Minimum. Science 192: 1189-1202

$>$ EPICA (European Project for Ice Coring in Antarctica) Community Members (2006) One-to-one coupling of glacial climate variability in Greenland and Antarctica. Nature 444:195-198

Fischer H, Schmitt J, Lüthi D, Stocker TF and others (2010) The role of Southern Ocean processes in orbital and millennial $\mathrm{CO}_{2}$ variations: a synthesis. Quat Sci Rev 29: 193-205

Fleitmann D, Burns SJ, Mudelsee M, Neff U, Kramers J, Mangini A, Matter A (2003) Holocene forcing of the Indian monsoon recorded in a stalagmite from southern Oman. Science 300:1737-1739

Haflidason H, Sejrup HP, Kristensen DK, Johnsen S (1995) Coupled response of the late glacial climatic shifts of northwest Europe reflected in Greenland ice cores: evidence from the northern North Sea. Geology 23: 1059-1062

Hammarlund D, Björck S, Buchardt B, Thomsen CT (2005) Limnic responses to increased effective humidity during the 8200 cal yr BP cooling event in southern Sweden. J Paleolimnol 34:471-480

IPCC (Intergovernmental Panel on Climate Change) (2007) Climate change 2007: the physical science basis. In: Solomon S, Qin D, Manning M, Chen Z and others (eds) Contribution of Working Group I to the Fourth Assessment Report of the Intergovernmental Panel on Climate Change. Cambridge University Press, Cambridge

Jönsson Sparrenbom C (2006) Constraining the southern part of the Greenland ice sheet since the Last Glacial Maxi- mum from relative sea-level changes, cosmogenic dates and glacial-isostatic adjustment models. PhD dissertation, Lund University, Lund

Kaufman DS, Schneider DP, McKay NP, Ammann CA and others (2009) Recent warming reverses long-term Arctic cooling. Science 325:1236-1239

Keller K, Yohe G, Schlesinger M (2008) Managing the risks of climate thresholds: uncertainties and information needs. Clim Change 91:5-10

Kopp RE, Simons FJ, Mitrovica JX, Maloof AC, Oppenheimer M (2009) Probabilistic assessment of sea level during the last interglacial. Nature 462:863-867

Lambeck K, Chappell J (2001) Sea level change through the Last Glacial cycle. Science 292:679-686

Lamy F, Hebbeln D, Röhl U, Wefer G (2001) Holocene rainfall variability in southern Chile: a marine record of latitudinal shifts of the southern westerlies. Earth Planet Sci Lett 185:369-382

Lea DW, Pak DK, Spero HJ (2000) Climate impact of Late Quaternary equatorial Pacific sea surface temperature variations. Science 289:1719-1724

> Ljung K, Björck S (2007) Holocene climate and vegetation dynamics on Nightingale Island, South Atlantic-an apparent interglacial bipolar seesaw in action? Quat Sci Rev 26:3150-3166

Marchitto TM, Lehman SJ, Ortiz JD, Flückiger J, van Geen A (2007) Marine radiocarbon evidence for the mechanism of deglacial atmospheric $\mathrm{CO}_{2}$ rise. Science 316:1456-1459

> Maslin MA, Smart CW (2010) Holocene bipolar climate seesaw: possible subtle evidence from the deep North East Atlantic Ocean? J Quaternary Sci 25:237-242

> Monnin E, Indermuhle A, Dallenbach A, Fluckiger J and others (2001) Atmospheric $\mathrm{CO}_{2}$ concentrations over the last glacial termination. Science 291:112-114

Muscheler R, Joos F, Beer J, Müller SA, Vonmoos M, Snowball I (2007) Solar activity during the last 1000 yr inferred from radionuclide records. Quat Sci Rev 26:82-97

> Otto-Bliesner BL, Marshall SJ, Overpeck JT, Miller GH, Hu A (2006) Simulating Arctic climate warmth and icefield retreat in the Last Interglaciation. Science 311:1751-1753

> Overpeck JT, Otto-Bliesner BL, Miller GH, Muhs DR, Alley RB, Kiehl JT (2006) Paleoclimatic evidence for future icesheet instability and rapid sea-level rise. Science 311: $1747-1750$

Peltier WR (2007) Postglacial coastal evolution: ice-oceansolid Earth interactions in a period of rapid climate change. In: Harff J, Hay WW, Tetzlaff D (eds) Coastline changes: interrelation of climate and geological processes. Geol Soc Am Spec Pap 426. The Geological Society of America, Boulder, CO, p 5-28

Renssen H, Goosse H, Fichefet T (2007) Simulation of Holocene cooling events in a coupled climate model. Quat Sci Rev 26:2019-2029

> Siddall M, Rohling EJ, Almogi-Labin A, Hemleben C, Meischner D, Schmelzer I, Smeed DA (2003) Sea-level fluctuations during the last glacial cycle. Nature 423:853-858

Stocker TF (1999) Abrupt climate changes: from the past to the future-a review. Int J Earth Sci 88:365-374

> Stott L, Timmermann A, Thunell R (2007) Southern Hemisphere and deep-sea warming led deglacial atmospheric $\mathrm{CO}_{2}$ rise and tropical warming. Science 318:435-438

Striberger J, Björck S, Snowball I, Ingólfsson Ó, Kjær K, Uvo CB (2009) Holocene surge history of the Eyjabakkajökull glacier inferred from varved lake sediments on eastern Iceland. Eos Trans AGU 90(52) Fall Meeting Suppl Abstract C23A-0489

Unkel I, Fernandez M, Björck S, Ljung K, Wohlfarth B (in 
press) Records of environmental changes during the Holocene from Isla de los Estados $\left(54.4^{\circ} \mathrm{S}\right)$, southeastern Tierra del Fuego. Global Planet Change

Usoskin IG, Solanki SK, Schüssler M, Mursula K, Alanko K (2003) A millennium scale sunspot number reconstruction: evidence for an unusually active sun since the 1940s. Phys Rev Lett 91:211101

Vinther BM, Buchardt SL, Clausen HB, Dahl-Jensen D and others (2009) Holocene thinning of the Greenland Ice Sheet. Nature 461:385-388

Walker M, Johnsen S, Olander Rasmussen S, Popp T and others (2009) Formal definition and dating of the GSSP (Global Stratotype Section and Point) for the base of the Holocene using the Greenland NGRIP ice core, and

Submitted: January 5, 2010; Accepted: May 3, 2010 selected auxiliary records. J Quaternary Sci 24:3-17

Wang YJ, Cheng H, Edwards RL, An ZS, Wu JY, Shen CC, Dorale JA (2001) A high-resolution absolute-dated late Pleistocene monsoon record from Hulu Cave, China. Science 294:2345-2348

Wang Y, Cheng H, Edwards RL, He Y and others (2005) The Holocene Asian monsoon: links to solar changes and North Atlantic climate. Science 308:854-857

Wanner H, Beer J, Bütikofer J, Crowley TJ and others (2008) Mid to late Holocene climate change: an overview. Quat Sci Rev 27:1791-1828

Yu KF, Zhao JX (2010) U-series dates of Great Barrier Reef corals suggest at least $+0.7 \mathrm{~m}$ sea level $\sim 7000$ years ago. Holocene 20:161-168

Proofs received from author(s): September 22, 2010 